\title{
Peroxynitrite scavenging by ferryl sperm whale myoglobin and human hemoglobin
}

\author{
Paolo Ascenzi ${ }^{\mathrm{a}, \mathrm{b}, *, 1}$, Elisabetta De Marinis ${ }^{\mathrm{a}, 1}$, Alessandra di Masi ${ }^{\mathrm{a}}$, Chiara Ciaccio $^{\mathrm{c}, \mathrm{d}}$, Massimo Coletta ${ }^{\mathrm{c}, \mathrm{d}}$ \\ a Department of Biology and Interdepartmental Laboratory for Electron Microscopy, University Roma Tre, Viale Guglielmo Marconi 446, I-00146 Roma, Italy \\ ${ }^{\mathrm{b}}$ National Institute for Infectious Diseases I.R.C.C.S. 'Lazzaro Spallanzani', Via Portuense 292, I-00149 Roma, Italy \\ ${ }^{\mathrm{c}}$ Department of Experimental Medicine and Biochemical Sciences, University of Roma 'Tor Vergata', Via Montpellier 1, I-00133 Roma, Italy \\ ${ }^{\mathrm{d}}$ Interuniversity Consortium for the Research on the Chemistry of Metals in Biological Systems, Via Celso Ulpiani 27, I-70121 Bari, Italy
}

\section{A R T I C L E I N F O}

\section{Article history:}

Received 8 September 2009

Available online 17 September 2009

\section{Keywords:}

Ferryl myoglobin reduction

Ferryl hemoglobin reduction

Ferric myoglobin formation

Ferric hemoglobin formation

Peroxynitrite scavenging

Effect of $\mathrm{CO}_{2}$

Kinetics

\begin{abstract}
A B S T R A C T
Globins protect from the oxidative and nitrosative cell damage. Here, kinetics of peroxynitrite scavenging by ferryl sperm whale myoglobin $(\mathrm{Mb}-\mathrm{Fe}(\mathrm{IV})=0)$ and human hemoglobin $(\mathrm{Hb}-\mathrm{Fe}(\mathrm{IV})=\mathrm{O})$, between $\mathrm{pH}$ 5.8 and 8.3 at $20.0{ }^{\circ} \mathrm{C}$, are reported. In the absence of $\mathrm{CO}_{2}$, values of the second-order rate constant for peroxynitrite scavenging by $\mathrm{Mb}-\mathrm{Fe}(\mathrm{IV})=\mathrm{O}$ and $\mathrm{Hb}-\mathrm{Fe}(\mathrm{IV})=\mathrm{O}$ (i.e., for $\mathrm{Mb}-\mathrm{Fe}(\mathrm{III})$ and $\mathrm{Hb}-\mathrm{Fe}$ (III) formation; $k_{\text {on }}$ ) are $4.6 \times 10^{4} \mathrm{M}^{-1} \mathrm{~s}^{-1}$ and $3.3 \times 10^{4} \mathrm{M}^{-1} \mathrm{~s}^{-1}$, respectively, at pH 7.1. Values of $k_{\text {on }}$ increase on decreasing $\mathrm{pH}$ with $\mathrm{p} K_{\mathrm{a}}$ values of 6.9 and 6.7 , this suggests that the $\mathrm{ONOOH}$ species reacts preferentially with $\mathrm{Mb}-\mathrm{Fe}(\mathrm{IV})=\mathrm{O}$ and $\mathrm{Hb}-\mathrm{Fe}(\mathrm{IV})=\mathrm{O}$. In the presence of $\mathrm{CO}_{2}\left(=1.2 \times 10^{-3} \mathrm{M}\right)$, values of $k_{\text {on }}$ for peroxynitrite scavenging by $\mathrm{Mb}-\mathrm{Fe}(\mathrm{IV})=\mathrm{O}$ and $\mathrm{Hb}-\mathrm{Fe}(\mathrm{IV})=\mathrm{O}$ are essentially $\mathrm{pH}$-independent, the average $k_{\text {on }}$ values are $7.1 \times 10^{4} \mathrm{M}^{-1} \mathrm{~s}^{-1}$ and $1.2 \times 10^{5} \mathrm{M}^{-1} \mathrm{~s}^{-1}$, respectively. As a whole, $\mathrm{Mb}-\mathrm{Fe}(\mathrm{IV})=\mathrm{O}$ and $\mathrm{Hb}-\mathrm{Fe}(\mathrm{IV})=\mathrm{O}$, obtained by treatment with $\mathrm{H}_{2} \mathrm{O}_{2}$, undertake within the same cycle $\mathrm{H}_{2} \mathrm{O}_{2}$ and peroxynitrite detoxification.
\end{abstract}

(c) 2009 Elsevier Inc. All rights reserved.
Peroxynitrite is implicated in several physiological and pathological events, including cell signaling, drug metabolism, microbial pathogenesis, atherosclerosis, inflammation, and neurodegenerative disorders. It reacts with various bio-molecules including proteins, lipids, and DNA by either direct reaction with a target molecule or immediately after homolysis to $\mathrm{NO}_{2}$ and hydroxyl radical $(\cdot \mathrm{OH})$ or after reaction with $\mathrm{CO}_{2}$ and homolysis to $\mathrm{CO}_{3}{ }^{-}$ and $\mathrm{NO}_{2}[1-11]$.

Besides their role in $\mathrm{O}_{2}$ transport and storage, globins also catalyze several reactions aimed to scavenge toxic reactive nitrogen and oxygen species. These reactions play an important physiological role in the defense against nitrosative and oxidative stress [7,12-16]. Peroxynitrite scavenging has been reported to be facilitated by the ferrous oxygenated (heme- $\mathrm{Fe}(\mathrm{II})-\mathrm{O}_{2}$ ), ferrous nitrosylated (heme-Fe(II)-NO), and ferric (heme-Fe(III)) derivatives of heme-proteins $[7,15,17-29]$.

\footnotetext{
Abbreviations: Fe(III), ferric heme-protein; $\mathrm{Fe}(\mathrm{IV})=\mathrm{O}$, ferryl [oxo-Fe(IV)] hemeprotein; $\mathrm{Fe}(\mathrm{II})-\mathrm{NO}$, ferrous nitrosylated heme-protein; $\mathrm{Fe}(\mathrm{II})-\mathrm{O}_{2}$, ferrous oxygenated heme-protein; $\mathrm{Hb}$, hemoglobin; Lb, leghemoglobin; Mb, myoglobin; trHbO, truncated $\mathrm{HbO}$

* Corresponding author. Address: Department of Biology and Interdepartmental Laboratory for Electron Microscopy, University Roma Tre, Viale Guglielmo Marconi 446, I-00146 Roma, Italy. Fax: +39 0657336321.

E-mail address: ascenzi@uniroma3.it (P. Ascenzi).

1 These Authors contributed equally to this study.
}

Here, a detailed kinetic study of peroxynitrite scavenging by the ferryl derivative of sperm whale $\mathrm{Mb}(\mathrm{Mb}-\mathrm{Fe}(\mathrm{IV})=0)$ and human $\mathrm{Hb}(\mathrm{Hb}-\mathrm{Fe}(\mathrm{IV})=\mathrm{O})$ is reported. $\mathrm{Mb}-\mathrm{Fe}(\mathrm{IV})=\mathrm{O}$ and $\mathrm{Hb}-\mathrm{Fe}(\mathrm{IV})=\mathrm{O}$, obtained by treatment with hydrogen peroxide $\left(\mathrm{H}_{2} \mathrm{O}_{2}\right)$, catalyze peroxynitrite scavenging. In turn, peroxynitrite acts as an antioxidant of $\mathrm{Mb}-\mathrm{Fe}(\mathrm{IV})=\mathrm{O}$ and $\mathrm{Hb}-\mathrm{Fe}(\mathrm{IV})=\mathrm{O}$ and could prevent cell damage. Therefore, $\mathrm{Mb}$ and $\mathrm{Hb}$ appear to be involved in both $\mathrm{H}_{2} \mathrm{O}_{2}$ and peroxynitrite scavenging.

\section{Materials}

Ferric sperm whale $\mathrm{Mb}(\mathrm{Mb}-\mathrm{Fe}(\mathrm{III}))$ was obtained from SigmaAldrich (St. Louis, MO, USA). Ferrous oxygenated sperm whale Mb $\left(\mathrm{Mb}-\mathrm{Fe}(\mathrm{II})-\mathrm{O}_{2}\right)$ was prepared by adding few grains of sodium dithionite to the $\mathrm{Mb}-\mathrm{Fe}(\mathrm{III})$ solution, then the solution was desalted by passing it throughout a G25 Sephadex gel filtration column equilibrated in air with $1.0 \times 10^{-1} \mathrm{M}$ phosphate buffer, at $\mathrm{pH}$ 7.2 and $20^{\circ} \mathrm{C}[30]$. Ferrous oxygenated human $\mathrm{Hb}\left(\mathrm{Hb}-\mathrm{Fe}(\mathrm{II})-\mathrm{O}_{2}\right)$ was prepared from blood samples according to literature [30]. Ferric human $\mathrm{Hb}(\mathrm{Hb}-\mathrm{Fe}(\mathrm{III}))$ was prepared by adding a few grains of sodium ferricyanide to the $\mathrm{Hb}-\mathrm{Fe}(\mathrm{II})-\mathrm{O}_{2}$ solution [30]. Sperm whale $\mathrm{Mb}-\mathrm{Fe}(\mathrm{IV})=\mathrm{O}$ and human $\mathrm{Hb}-\mathrm{Fe}(\mathrm{IV})=0$ were prepared by adding 7-15 equivalents of $\mathrm{H}_{2} \mathrm{O}_{2}$ to the $\mathrm{Mb}-\mathrm{Fe}(\mathrm{III})$ and $\mathrm{Hb}-\mathrm{Fe}(\mathrm{III})$ solutions $\left(5.0 \times 10^{-2} \mathrm{M}\right.$ phosphate buffer, $\left.\mathrm{pH} 7.2\right)$ at $20.0^{\circ} \mathrm{C}$. After a reaction time of few minutes, the $\mathrm{Mb}-\mathrm{Fe}(\mathrm{IV})=\mathrm{O}$ and $\mathrm{Hb}-\mathrm{Fe}(\mathrm{IV})=\mathrm{O}$ 


$$
\begin{gathered}
k_{\text {on }} \\
\text { heme-Fe(IV) }=\mathrm{O}+\text { peroxynitrite } \rightarrow \text { heme-Fe(III) }
\end{gathered}
$$

Scheme 1.

solutions were stored on ice and used within $1 \mathrm{~h}$. The heme-protein concentration was determined spectrophotometrically with $\varepsilon$ values listed in Supplementary Table 1.

The solutions of the experiments in the presence of $\mathrm{CO}_{2}$ were prepared by adding the required amount of a $5.0 \times 10^{-1} \mathrm{M} \mathrm{NaHCO}_{3}$ solution [15,19,21,22,24,25,29].

$\mathrm{H}_{2} \mathrm{O}_{2}$ (from Fluka GmbH, Buchs, Switzerland) was diluted with the $5.0 \times 10^{-2} \mathrm{M}$ phosphate buffer solution ( $\mathrm{pH} 7.2$ ); the $\mathrm{H}_{2} \mathrm{O}_{2}$ concentration was determined spectrophotometrically at $240 \mathrm{~nm}$ $\left(\varepsilon_{240 \mathrm{~nm}}=3.94 \times 10^{1} \mathrm{M}^{-1} \mathrm{~cm}^{-1}\right)[31]$.

Peroxynitrite was prepared from potassium superoxide $\left(\mathrm{KO}_{2}\right)$ and $\mathrm{NO}$ and from nitrous acid $\left(\mathrm{HNO}_{2}\right)$ and $\mathrm{H}_{2} \mathrm{O}_{2}$ [32,33]. The peroxynitrite stock solution was diluted with degassed $1.0 \times 10^{-2} \mathrm{M}$ sodium hydroxide $(\mathrm{NaOH})$ to reach the desired concentration. The peroxynitrite concentration was determined spectrophotometrically at $302 \mathrm{~nm}\left(\varepsilon_{302 \mathrm{~nm}}=1.67 \times 10^{3} \mathrm{M}^{-1} \mathrm{~cm}^{-1}\right)$ [34].

All the other products (from Merck AG, Darmstadt, Germany, or Sigma-Aldrich, St. Louis, MO, USA) were of analytical grade and used without purification.

\section{Methods}

Kinetics of peroxynitrite scavenging by sperm whale $\mathrm{Mb}-\mathrm{Fe}-$ $(\mathrm{IV})=\mathrm{O}$ and human $\mathrm{Hb}-\mathrm{Fe}(\mathrm{IV})=\mathrm{O}$ were determined, in the absence and presence of $\mathrm{CO}_{2}$, by rapid mixing the $\mathrm{Mb}-\mathrm{Fe}(\mathrm{IV})=\mathrm{O}$ and $\mathrm{Hb}-\mathrm{Fe}(\mathrm{IV})=\mathrm{O}$ solutions (final concentration, $3.2 \times 10^{-6}$ and $2.9 \times 10^{-6} \mathrm{M}$, respectively) with the peroxynitrite solution (final concentration, $2.0 \times 10^{-5}$ to $4.0 \times 10^{-4} \mathrm{M}$ ), at $\mathrm{pH}$ values ranging between 5.8 and 8.3 (final concentration, $2.0 \times 10^{-1} \mathrm{M}$ phosphate buffer) and $20.0^{\circ} \mathrm{C}$; no gaseous phase was present. Kinetics was monitored between 360 and $460 \mathrm{~nm}$ [15,19,21,23-29].

The time course of peroxynitrite scavenging by $\mathrm{Mb}-\mathrm{Fe}(\mathrm{IV})=\mathrm{O}$ and $\mathrm{Hb}-\mathrm{Fe}(\mathrm{IV})=\mathrm{O}$, in the absence and presence of $\mathrm{CO}_{2}$, was fitted to a single exponential process according to the minimum reaction mechanism represented by Scheme 1 [29].

Values of the pseudo-first-order rate constant $k$ for peroxynitrite scavenging by $\mathrm{Mb}-\mathrm{Fe}(\mathrm{IV})=\mathrm{O}$ and $\mathrm{Hb}-\mathrm{Fe}(\mathrm{IV})=\mathrm{O}$, in the absence and presence of $\mathrm{CO}_{2}$, were determined according to Eq. (1) [29]:

$[\mathrm{Fe}(\mathrm{IV})=\mathrm{O}]_{t}=[\mathrm{Fe}(\mathrm{IV})=\mathrm{O}]_{i} \times \mathrm{e}^{-k \times t}$

Values of $k_{\text {on }}$, in the absence and presence of $\mathrm{CO}_{2}$, were determined according to Eq. (2) [29]:

$k=k_{\text {on }} \times$ [peroxynitrite $]+a$

where $a$ is the value of $k$ in the absence of peroxynitrite.

The $\mathrm{p} K_{\mathrm{a}}$ values describing the $\mathrm{pH}$-dependence of $k_{\text {on }}$ for peroxynitrite scavenging by $\mathrm{Mb}-\mathrm{Fe}(\mathrm{IV})=\mathrm{O}$ and $\mathrm{Hb}-\mathrm{Fe}(\mathrm{IV})=\mathrm{O}$, in the $\mathrm{ab}-$ sence of $\mathrm{CO}_{2}$, were obtained, at $20.0^{\circ} \mathrm{C}$, according to Eq. (3) [29]:

$$
\begin{aligned}
k_{\text {on }}= & \left(\left(k_{\lim (\text { top })}-k_{\lim (\text { bottom })}\right) \times 10^{-\mathrm{pH}}\right) /\left(10^{-\mathrm{pH}}+10^{-\mathrm{pKa}}\right) \\
& +k_{\lim (\text { bottom })}
\end{aligned}
$$

where $k_{\lim (\text { top) }}$ and $k_{\lim (\text { bottom) }}$ represent the asymptotic values of $k_{\text {on }}$ under conditions where $\mathrm{pH} \ll \mathrm{p} K_{\mathrm{a}}$ and $\mathrm{pH} \gg \mathrm{p} K_{\mathrm{a}}$, respectively.
In some cases, catalase was added to the $\mathrm{Mb}-\mathrm{Fe}(\mathrm{IV})=\mathrm{O}$ and $\mathrm{Hb}-\mathrm{Fe}(\mathrm{IV})=\mathrm{O}$ solutions prior to reaction with peroxynitrite to destroy excess $\mathrm{H}_{2} \mathrm{O}_{2}$. According to literature [29,35,36], catalase does not affect peroxynitrite scavenging by $\mathrm{Mb}-\mathrm{Fe}(\mathrm{IV})=\mathrm{O}$ and $\mathrm{Hb}-\mathrm{Fe}(\mathrm{IV})=\mathrm{O}$, in the absence and presence of $\mathrm{CO}_{2}$.

Kinetics of peroxynitrite scavenging by sperm whale $\mathrm{Mb}-\mathrm{Fe}(\mathrm{II})-$ $\mathrm{O}_{2}$ and human $\mathrm{Hb}-\mathrm{Fe}(\mathrm{II})-\mathrm{O}_{2}$ were determined, in the absence and presence of $\mathrm{CO}_{2}$, by rapid mixing the $\mathrm{Mb}-\mathrm{Fe}(\mathrm{II})-\mathrm{O}_{2}$ and $\mathrm{Hb}-\mathrm{Fe}-$ (II) $-\mathrm{O}_{2}$ solutions (final concentration, $3.4 \times 10^{-6}$ and $3.3 \times$ $10^{-6} \mathrm{M}$, respectively) with the peroxynitrite solution (final concentration, $2.0 \times 10^{-5}$ to $4.0 \times 10^{-4} \mathrm{M}$ ), at $\mathrm{pH} 7.1$ (final concentration, $2.0 \times 10^{-1} \mathrm{M}$ phosphate buffer) and $20.0^{\circ} \mathrm{C}$; no gaseous phase was present. Kinetics was monitored between 360 and 460 nm [19,22, 24,25].

The time course of peroxynitrite scavenging by sperm whale $\mathrm{Mb}-\mathrm{Fe}(\mathrm{II})-\mathrm{O}_{2}$ and human $\mathrm{Hb}-\mathrm{Fe}(\mathrm{II})-\mathrm{O}_{2}$, in the absence and presence of $\mathrm{CO}_{2}$, was fitted to two consecutive mono-exponential processes according to the minimum reaction mechanism represented by Scheme 2 [19,22,24,25].

Values of the pseudo-first-order rate constants $h$ and $k$ for peroxynitrite scavenging by $\mathrm{Mb}-\mathrm{Fe}(\mathrm{II})-\mathrm{O}_{2}$ and $\mathrm{Hb}-\mathrm{Fe}(\mathrm{II})-\mathrm{O}_{2}$, in the absence and presence of $\mathrm{CO}_{2}$, were determined according to Eqs. $(4 a-c)$ [37]:

$$
\begin{aligned}
{\left[\mathrm{Fe}(\mathrm{II})-\mathrm{O}_{2}\right]_{t}=} & {\left[\mathrm{Fe}(\mathrm{II})-\mathrm{O}_{2}\right]_{i} \times \mathrm{e}^{-h \times t} } \\
{[\mathrm{Fe}(\mathrm{IV})=\mathrm{O}]_{t}=} & {\left[\mathrm{Fe}(\mathrm{II})-\mathrm{O}_{2}\right]_{i} \times\left(h \times\left(\left(\mathrm{e}^{-h \times t} /(k-h)\right)\right.\right.} \\
& \left.\left.+\left(\mathrm{e}^{-k \times t} /(h-k)\right)\right)\right)
\end{aligned}
$$

$[\mathrm{Fe}(\mathrm{III})]_{t}=\left[\mathrm{Fe}(\mathrm{II})-\mathrm{O}_{2}\right]_{i}-\left[\mathrm{Fe}(\mathrm{II})-\mathrm{O}_{2}\right]_{t}+[\mathrm{Fe}(\mathrm{IV})=\mathrm{O}]_{t}$

Values of $h_{\text {on }}$ and $k_{\text {on }}$, in the absence and presence of $\mathrm{CO}_{2}$, were determined according to Eqs. (5a) and (5b) [29]:

$h=h_{\text {on }} \times[$ peroxynitrite $]+a$

$k=k_{\text {on }} \times$ [peroxynitrite $]+a$

where $a$ is the value of $h$ or $k$ in the absence of peroxynitrite.

The results are given as mean values of at least four experiments plus or minus the corresponding standard deviation. All data were analyzed using the MatLab program (The Math Works Inc., Natick, MA, USA).

\section{Results and discussion}

Mixing of sperm whale $\mathrm{Mb}-\mathrm{Fe}(\mathrm{IV})=\mathrm{O}$ or human $\mathrm{Hb}-\mathrm{Fe}(\mathrm{IV})=\mathrm{O}$ with peroxynitrite solutions, in the absence and presence of $\mathrm{CO}_{2}$, leads to the formation of $\mathrm{Mb}-\mathrm{Fe}(\mathrm{III})$ and $\mathrm{Hb}-\mathrm{Fe}(\mathrm{III})$, respectively. Under all the experimental conditions, the time course of peroxynitrite scavenging by $\mathrm{Mb}-\mathrm{Fe}(\mathrm{IV})=\mathrm{O}$ and $\mathrm{Hb}-\mathrm{Fe}(\mathrm{IV})=\mathrm{O}$ corresponds to a monophasic process (Scheme 1). Moreover, values of $k$ for peroxynitrite scavenging by $\mathrm{Mb}-\mathrm{Fe}(\mathrm{IV})=\mathrm{O}$ and $\mathrm{Hb}-\mathrm{Fe}(\mathrm{IV})=\mathrm{O}$ are wavelength-independent under pseudo-first order conditions at fixed peroxynitrite concentration and $\mathrm{pH}$ (data not shown).

Plots of $k$ versus [peroxynitrite] are linear, the slope corresponds to $k_{\text {on }}$ (Figs. 1 and 2). In the absence of $\mathrm{CO}_{2}$, the $y$-axis intercept of plots of $k$ versus [peroxynitrite] (i.e., $a$; see Eq. (2)) corresponds to $a \cong 0 \mathrm{~s}^{-1}$ (Figs. 1 and 2 and Supplementary Tables 2 and 3). On the other hand, in the presence of $\mathrm{CO}_{2}$ (Figs. 1 and 2 and Supplementary Tables 2 and 3 ), the $y$-axis intercept of plots

\footnotetext{
$h_{\text {on }} \quad k_{\text {on }}$

heme-Fe(II)- $\mathrm{O}_{2}+$ peroxynitrite $\rightarrow$ heme-Fe(IV)=O + peroxynitrite $\rightarrow$ heme-Fe(III)
} 

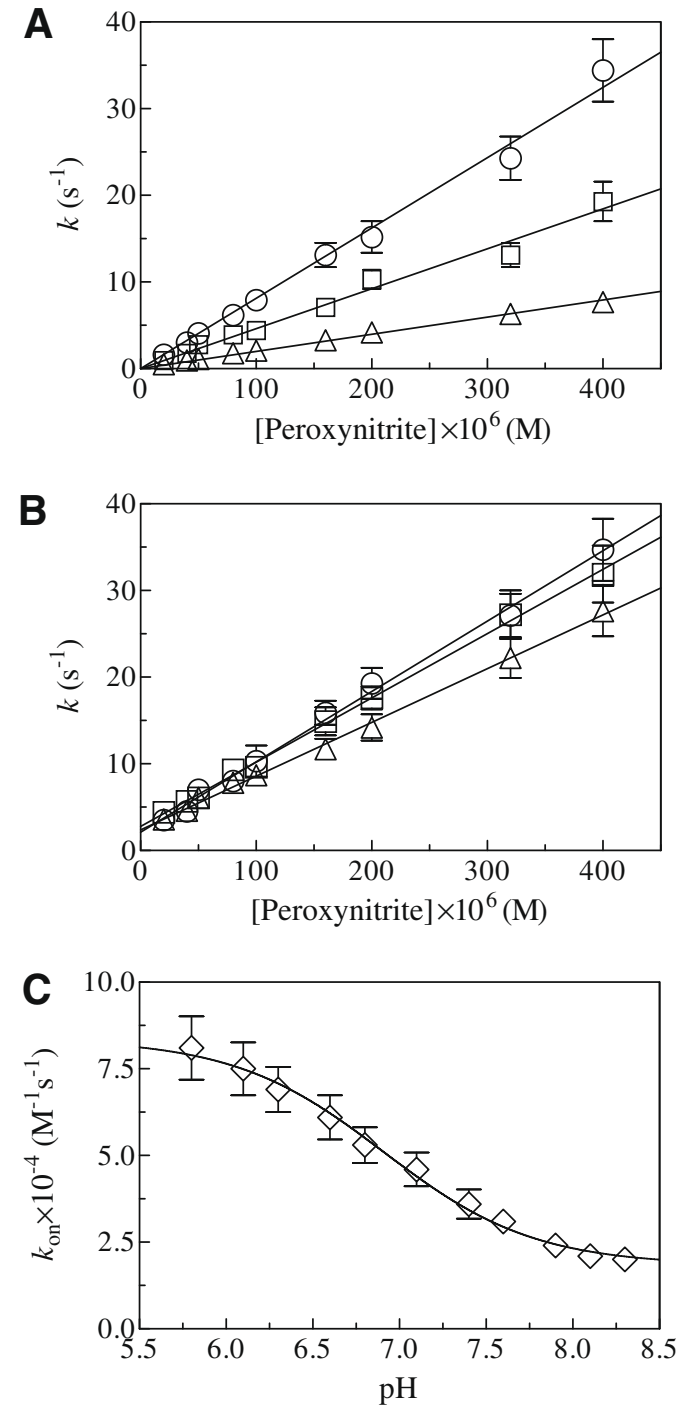

Fig. 1. Kinetics of peroxynitrite scavenging by sperm whale $\mathrm{Mb}-\mathrm{Fe}(\mathrm{IV})=\mathrm{O}$, at $20.0^{\circ} \mathrm{C}$. (A) Dependence of $k$ on the peroxynitrite concentration, in the absence of $\mathrm{CO}_{2}$, at pH $5.8,7.1$, and 8.3 (circles, squares, and triangles, respectively). The analysis of data according to Eq. (2) allowed to determine $k_{\text {on }}=8.1 \times 10^{4} \mathrm{M}^{-1} \mathrm{~s}^{-1}$ (circles), $4.6 \times 10^{4} \mathrm{M}^{-1} \mathrm{~s}^{-1}$ (squares), and $2.0 \times 10^{4} \mathrm{M}^{-1} \mathrm{~s}^{-1}$ (triangles). (B) Dependence of $k$ on the peroxynitrite concentration, in the presence of $\mathrm{CO}_{2}$, at $\mathrm{pH} 6.1,7.1$, and 7.9 (circles, squares, and triangles, respectively). The analysis of data according to Eq. (2) allowed to determine $k_{\mathrm{on}}=8.1 \times 10^{4} \mathrm{M}^{-1} \mathrm{~s}^{-1}$ and $a=2.1 \mathrm{~s}^{-1}$ (circles), $k_{\mathrm{on}}=7.4 \times$ $10^{4} \mathrm{M}^{-1} \mathrm{~s}^{-1}$ and $a=2.8 \mathrm{~s}^{-1}$ (squares), and $k_{\mathrm{on}}=6.2 \times 10^{4} \mathrm{M}^{-1} \mathrm{~s}^{-1}$ and $a=2.4 \mathrm{~s}^{-1}$ (triangles). (C) pH-dependence of $k_{\text {on }}$ in the absence of $\mathrm{CO}_{2}$. The analysis of data according to Eq. (3) allowed to determine $\mathrm{p} K_{\mathrm{a}}=6.9 \pm 0.1, k_{\lim (\text { top })}=(8.4 \pm 0.2) \times$ $10^{4} \mathrm{M}^{-1} \mathrm{~s}^{-1}$, and $k_{\mathrm{lim}(\text { bottom) }}=(1.8 \pm 0.1) \times 10^{4} \mathrm{M}^{-1} \mathrm{~s}^{-1}$. Where not shown, standard deviation is smaller than the symbol. The $\mathrm{Mb}-\mathrm{Fe}(\mathrm{IV})=\mathrm{O}$ concentration was $3.2 \times 10^{-6} \mathrm{M}$. The $\mathrm{CO}_{2}$ concentration was $1.2 \times 10^{-3} \mathrm{M}$. For details, see text.

of $k$ versus [peroxynitrite] shows values of $a$ ranging between 2.1 and $6.2 \mathrm{~s}^{-1}$ at different $\mathrm{pH}$ values. Since peroxynitrite scavenging by $\mathrm{Mb}-\mathrm{Fe}(\mathrm{IV})=\mathrm{O}$ and $\mathrm{Hb}-\mathrm{Fe}(\mathrm{IV})=\mathrm{O}$ is not likely to be a reversible process, $2.1 \geqslant a \geqslant 6.2 \mathrm{~s}^{-1}$ may be indicative of a reaction mechanism more complex than that reported in Scheme 1 [19,22,24,25].

As shown in Figs. 1 and 2 and Supplementary Tables 2 and 3 , values of $k_{\text {on }}$ for peroxynitrite scavenging by $\mathrm{Mb}-\mathrm{Fe}(\mathrm{IV})=\mathrm{O}$ and $\mathrm{Hb}-\mathrm{Fe}(\mathrm{IV})=\mathrm{O}$ increase on decreasing $\mathrm{pH}$ from 8.3 to 5.8 , in the absence of $\mathrm{CO}_{2}$; the analysis of data according to Eq. (3) allowed to determine values of $\mathrm{p} K_{\mathrm{a}}=6.9$ and 6.7 , respectively. The $\mathrm{p} K_{\mathrm{a}}$ values for peroxynitrite scavenging by $\mathrm{Mb}-\mathrm{Fe}(\mathrm{IV})=\mathrm{O} \quad(=6.9)$ and $\mathrm{Hb}-\mathrm{Fe}(\mathrm{IV})=\mathrm{O}(=6.7)$, in the absence of $\mathrm{CO}_{2}$, are similar to those reported for: (i) peroxynitrite detoxification by ferryl Mycobacterium leprae truncated $\mathrm{HbO}(=6.7 ; \operatorname{trHbO}-\mathrm{Fe}(\mathrm{IV})=0)[29]$, and (ii) the
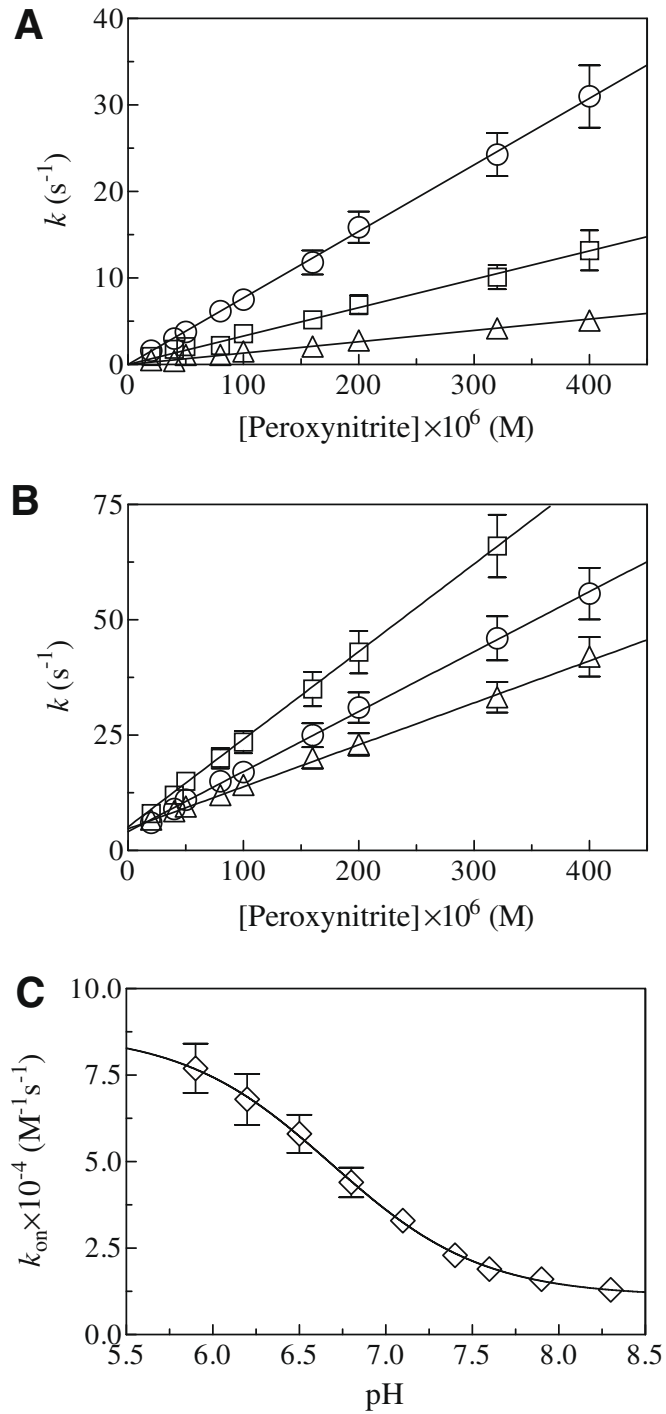

Fig. 2. Kinetics of peroxynitrite scavenging by human $\mathrm{Hb}-\mathrm{Fe}(\mathrm{IV})=\mathrm{O}$, at $20.0^{\circ} \mathrm{C}$. (A) Dependence of $k$ on the peroxynitrite concentration, in the absence of $\mathrm{CO}_{2}$, at $\mathrm{pH} 5.9$, 7.1 , and 8.2 (circles, squares, and triangles, respectively). The analysis of data according to Eq. (2) allowed to determine $k_{\mathrm{on}}=7.7 \times 10^{4} \mathrm{M}^{-1} \mathrm{~s}^{-1}$ (circles), $3.3 \times 10^{4} \mathrm{M}^{-1} \mathrm{~s}^{-1}$ (squares), and $1.3 \times 10^{4} \mathrm{M}^{-1} \mathrm{~s}^{-1}$ (triangles). (B) Dependence of $k$ on the peroxynitrite concentration, in the presence of $\mathrm{CO}_{2}$, at $\mathrm{pH} 5.9,7.1$, and 8.2 (circles, squares, and triangles, respectively). The analysis of data according to Eq. (2) allowed to determine $k_{\mathrm{on}}=1.3 \times 10^{5} \mathrm{M}^{-1} \mathrm{~s}^{-1}$ and $a=4.1 \mathrm{~s}^{-1}$ (circles), $k_{\mathrm{on}}=1.9 \times$ $10^{5} \mathrm{M}^{-1} \mathrm{~s}^{-1}$ and $a=5.1 \mathrm{~s}^{-1}$ (squares), and $k_{\mathrm{on}}=9.1 \times 10^{4} \mathrm{M}^{-1} \mathrm{~s}^{-1}$ and $a=4.7 \mathrm{~s}^{-1}$ (triangles). (C) pH-dependence of $k_{\text {on }}$ in the absence of $\mathrm{CO}_{2}$. The analysis of data according to Eq. (3) allowed to determine $\mathrm{p} K_{\mathrm{a}}=6.7 \pm 0.2, k_{\lim (\text { top })}=(8.7 \pm 0.9) \times$ $10^{4} \mathrm{M}^{-1} \mathrm{~s}^{-1}$, and $k_{\text {lim(bottom })}=(1.1 \pm 0.1) \times 10^{4} \mathrm{M}^{-1} \mathrm{~s}^{-1}$. The $\mathrm{Hb}-\mathrm{Fe}(\mathrm{IV})=0$ concentration was $2.9 \times 10^{-6} \mathrm{M}$. The $\mathrm{Co}_{2}$ concentration was $1.2 \times 10^{-3} \mathrm{M}$. For details, see text and Fig. 1.

peroxynitrous acid/peroxynitrite (i.e., $\mathrm{ONOOH} / \mathrm{ONOO}$ ) equilibrium $(=6.5-6.8)[10,34]$. This suggests that peroxynitrous acid is the species that reacts preferentially with heme-Fe(IV) $=0$. According to Eq. (3), $k_{\lim (\text { top })}$ and $k_{\lim (\text { bottom) }}$ could represent the second-order rate constants for $\mathrm{Mb}-\mathrm{Fe}(\mathrm{IV})=\mathrm{O}$ - and $\mathrm{Hb}-\mathrm{Fe}(\mathrm{IV})=\mathrm{O}$-mediated scavenging of peroxynitrous acid at $\mathrm{pH} \ll \mathrm{p} K_{\mathrm{a}}$ and of peroxynitrite at $\mathrm{pH} \gg \mathrm{p} K_{\mathrm{a}}$, respectively. In agreement with: (i) kinetics of peroxynitrite scavenging by $M$. leprae trHbO-Fe(IV) $=0$ [29], and (ii) kinetic simulations concerning peroxynitrite scavenging by horse heart $\mathrm{Mb}-\mathrm{Fe}(\mathrm{IV})=\mathrm{O}$ [19], $k_{\mathrm{lim} \text { (top) }}$ values for peroxynitrite scavenging by $\mathrm{Mb}-\mathrm{Fe}(\mathrm{IV})=\mathrm{O}$ and $\mathrm{Hb}-\mathrm{Fe}(\mathrm{IV})=0$ exceed those of $k_{\lim \text { (bottom) }}$ (i.e., $k_{\lim (t o p)} / k_{\lim (\text { bottom })}=4.7$ and 7.9 , respectively). Accordingly, the reaction of $\mathrm{Hb}-\mathrm{Fe}(\mathrm{IV})=\mathrm{O}$ with $\mathrm{ONOOH}$ shows a lower activa- 
tion barrier (by about $5.1 \mathrm{~kJ} \mathrm{~mol}^{-1}$ ) with respect to that with $\mathrm{ONOO}^{-}$. In the case of $\mathrm{Mb}-\mathrm{Fe}(\mathrm{IV})=0$, the reactivity difference between $\mathrm{ONOOH}$ and $\mathrm{ONOO}^{-}$is much lower (amounting to about $3.7 \mathrm{~kJ} \mathrm{~mol}^{-1}$ ).

In the presence of $\mathrm{CO}_{2}$, values of $k_{\text {on }}$ for peroxynitrite scavenging by $\mathrm{Mb}-\mathrm{Fe}(\mathrm{IV})=\mathrm{O}$ and $\mathrm{Hb}-\mathrm{Fe}(\mathrm{IV})=\mathrm{O}$ are $\mathrm{pH}$-independent (the average $k_{\text {on }}$ values are $7.1 \times 10^{4} \mathrm{M}^{-1} \mathrm{~s}^{-1}$ and $1.2 \times 10^{5} \mathrm{M}^{-1} \mathrm{~s}^{-1}$, respectively; Figs. 1 and 2, and Supplementary Tables 2 and 3), as reported for $M$. leprae trHbO-Fe(IV) $=0$, Glycine max leghemoglobin-Fe $(I V)=O($ Lb-Fe $(I V)=0)$, horse heart $\mathrm{Mb}-\mathrm{Fe}(\mathrm{IV})=\mathrm{O}$, and human $\mathrm{Hb}-\mathrm{Fe}(\mathrm{IV})=\mathrm{O}[19,22,24,29]$. This agrees with the reaction mechanism proposed for peroxynitrite scavenging by heme$\mathrm{Fe}(\mathrm{IV})=\mathrm{O}$ in the presence of $\mathrm{CO}_{2}$ involving the transient highly reactive species ${ }^{\circ} \mathrm{NO}_{2}$. The formation of ${ }^{\circ} \mathrm{NO}_{2}$, possibly representing the rate-limiting step of the whole process, does not depend on the $\mathrm{ONOOH} \leftrightarrow \mathrm{ONOO}^{-}+\mathrm{H}^{+}$equilibrium (and thus on $\mathrm{pH}$ ), but instead on the $\mathrm{CO}_{2}$ concentration $[19,22,24,29]$. Also values of $a$ for peroxynitrite scavenging by $\mathrm{Mb}-\mathrm{Fe}(\mathrm{IV})=\mathrm{O}$ and $\mathrm{Hb}-\mathrm{Fe}(\mathrm{IV})=\mathrm{O}$ in the presence of $\mathrm{CO}_{2}$ are $\mathrm{pH}$-independent (the average $a$ values are 2.9 and $4.9 \mathrm{~s}^{-1}$, respectively) (see Supplementary Tables 2 and 3 ).

To support the kinetic mechanism of peroxynitrite scavenging by $\mathrm{Mb}-\mathrm{Fe}(\mathrm{IV})=\mathrm{O}$ and $\mathrm{Hb}-\mathrm{Fe}(\mathrm{IV})=\mathrm{O}$ (Scheme 1$)$, kinetics of peroxynitrite detoxification by sperm whale $\mathrm{Mb}-\mathrm{Fe}(\mathrm{II})-\mathrm{O}_{2}$ and human $\mathrm{Hb}-\mathrm{Fe}(\mathrm{II})-\mathrm{O}_{2}$ were investigated. Mixing of $\mathrm{Mb}-\mathrm{Fe}(\mathrm{II})-\mathrm{O}_{2}$ or $\mathrm{Hb}-\mathrm{Fe}(\mathrm{II})-\mathrm{O}_{2}$ with peroxynitrite solutions, in the absence and presence of $\mathrm{CO}_{2}$, leads to the formation of $\mathrm{Mb}-\mathrm{Fe}(\mathrm{III})$ and $\mathrm{Hb}-$ $\mathrm{Fe}(\mathrm{III})$, respectively, via the transient formation of $\mathrm{Mb}-\mathrm{Fe}(\mathrm{IV})=\mathrm{O}$ and $\mathrm{Hb}-\mathrm{Fe}(\mathrm{IV})=0$, respectively. Under all the experimental conditions, the time course for peroxynitrite scavenging by $\mathrm{Mb}-\mathrm{Fe}(\mathrm{II})$ $-\mathrm{O}_{2}$ and $\mathrm{Hb}-\mathrm{Fe}(\mathrm{II})-\mathrm{O}_{2}$ corresponds to a biphasic process (Scheme 2 ). Moreover, values of $h$ and $k$ for peroxynitrite scavenging by $\mathrm{Mb}-\mathrm{Fe}(\mathrm{III})$ and $\mathrm{Hb}-\mathrm{Fe}(\mathrm{III})$ are wavelength-independent under pseudo-first order conditions at fixed peroxynitrite concentration (data not shown).

Plots of $h$ and $k$ versus [peroxynitrite] are linear, the slope corresponds to $h_{\text {on }}$ and $k_{\text {on }}$ (see Eqs. (5a) and (5b)) (Supplementary Figs. 1 and 2). In the absence of $\mathrm{CO}_{2}$, the $y$-axis intercept of plots of $h$ and $k$ versus [peroxynitrite] corresponds to $a \cong 0 \mathrm{~s}^{-1}$ (Supplementary Figs. 1 and 2). On the other hand, in the presence of $\mathrm{CO}_{2}$ (Supplementary Figs. 1 and 2), the $y$-axis intercept of plots of $h$ and $k$ versus [peroxynitrite] display values of $a$ ranging between $4.7 \mathrm{~s}^{-1}$ and $1.2 \times 10^{1} \mathrm{~s}^{-1}$. Since peroxynitrite scavenging by $\mathrm{Mb}-\mathrm{Fe}(\mathrm{II})-\mathrm{O}_{2}$ and $\mathrm{Hb}-\mathrm{Fe}(\mathrm{II})-\mathrm{O}_{2}$ is not likely to be a reversible process, $4.7 \mathrm{~s}^{-1} \geqslant a \geqslant 1.2 \times 10^{1} \mathrm{~s}^{-1}$ may be indicative of a reaction mechanism more complex than that reported in Scheme 2 $[19,22,24,25]$.

Values of $k_{\text {on }}$ for peroxynitrite scavenging by $\mathrm{Mb}-\mathrm{Fe}(\mathrm{IV})=\mathrm{O}$ and $\mathrm{Mb}-\mathrm{Fe}(\mathrm{II})-\mathrm{O}_{2}$, and by $\mathrm{Hb}-\mathrm{Fe}(\mathrm{IV})=\mathrm{O}$ and $\mathrm{Hb}-\mathrm{Fe}(\mathrm{II})-\mathrm{O}_{2}$ match each other (Table 1), according to Schemes 1 and 2. Moreover, values of $h_{\text {on }}$ and $k_{\text {on }}$ for the peroxynitrite scavenging by $\mathrm{Hb}-\mathrm{Fe}(\mathrm{IV})=\mathrm{O}$ and $\mathrm{Hb}-\mathrm{Fe}(\mathrm{II})-\mathrm{O}_{2}$ are in agreement with those reported previously, in the absence and presence of $\mathrm{CO}_{2}$ [22] (see Table 1).

Values of $k_{\text {on }}$ for the peroxynitrite scavenging by sperm whale $\mathrm{Mb}$ and human $\mathrm{Hb}$ derivatives are grossly similar to those reported for M. leprae trHbO, Glycine max Lb, and horse heart Mb action (Table 1) $[19,22,24,29]$, indicating that the reactions depicted in Schemes 1 and 2 do not appear to reflect the different geometry of the heme-distal pocket. In fact, sperm whale $\mathrm{Mb}$, horse heart $\mathrm{Mb}$, and human $\mathrm{Hb}$ display the classical histidyl-based heme-distal pocket; the ligand entry to and exit from the heme-distal site occurs via the so-called 'E7-gate' [38-40]. On the other hand, the heme-distal region of $M$. leprae trHbO is completely different, indeed the HisE7 residue present in sperm whale Mb and human $\mathrm{Hb}$ chains is replaced by Ala [15,41]. Moreover, cavity systems present in the protein matrix appear to facilitate ligand entry to
Table 1

Values of kinetic parameters for peroxynitrite scavenging by ferryl and ferrous oxygenated heme-proteins (in italics and bold, respectively; see Schemes 1 and 2 respectively).

\begin{tabular}{|c|c|c|c|}
\hline Heme-protein & {$\left[\mathrm{CO}_{2}\right](\mathrm{M})$} & $h_{\mathrm{on}}\left(\mathrm{M}^{-1} \mathrm{~s}^{-1}\right)$ & $k_{\text {on }}\left(\mathrm{M}^{-1} \mathrm{~s}^{-1}\right)$ \\
\hline \multirow[t]{4}{*}{ Mycobacterium leprae trHbO } & $0^{\mathrm{a}}$ & - & $1.5 \times 10^{4 a}$ \\
\hline & $1.2 \times 10^{-3 a}$ & - & $2.2 \times 10^{4 a}$ \\
\hline & 0 & $4.8 \times 10^{4 b}$ & $1.3 \times 10^{4 b}$ \\
\hline & $1.2 \times 10^{-3 b}$ & $6.3 \times 10^{5 b}$ & $1.7 \times 10^{4 b}$ \\
\hline \multirow[t]{4}{*}{ Glycine $\max \mathrm{Lb}^{\mathrm{c}}$} & 0 & - & $3.4 \times 10^{4}$ \\
\hline & $1.2 \times 10^{-3}$ & - & $2.3 \times 10^{5}$ \\
\hline & 0 & $5.5 \times 10^{4}$ & $2.1 \times 10^{4}$ \\
\hline & $1.2 \times 10^{-3}$ & $8.8 \times 10^{5}$ & $3.6 \times 10^{5}$ \\
\hline \multirow[t]{4}{*}{ Sperm whale $\mathrm{Mb}^{\mathrm{d}}$} & 0 & - & $4.6 \times 10^{4}$ \\
\hline & $1.2 \times 10^{-3}$ & - & $7.4 \times 10^{4}$ \\
\hline & 0 & $7.3 \times 10^{4}$ & $3.8 \times 10^{4}$ \\
\hline & $1.2 \times 10^{-3}$ & $6.8 \times 10^{4}$ & $4.6 \times 10^{4}$ \\
\hline \multirow[t]{4}{*}{ Horse heart Mb } & $0^{\mathrm{e}}$ & - & $1.9 \times 10^{4 \mathrm{e}}$ \\
\hline & $1.2 \times 10^{-3 e}$ & - & $2.6 \times 10^{4 e}$ \\
\hline & $0^{f}$ & $5.4 \times 10^{4 f}$ & $2.2 \times 10^{4 f}$ \\
\hline & $1.2 \times 10^{-3 f}$ & $4.1 \times 10^{5 f}$ & $3.2 \times 10^{4 f}$ \\
\hline \multirow[t]{4}{*}{ Human $\mathrm{Hb}^{\mathrm{d}}$} & 0 & - & $3.3 \times 10^{4}$ \\
\hline & $1.2 \times 10^{-3}$ & - & $1.9 \times 10^{5}$ \\
\hline & 0 & $2.9 \times 10^{4}$ & $1.7 \times 104$ \\
\hline & $1.2 \times 10^{-3}$ & $2.1 \times 10^{5}$ & $1.6 \times 10^{5}$ \\
\hline
\end{tabular}

a $\mathrm{pH} 7.2$ and $20.0^{\circ} \mathrm{C}$. From [29].

$\mathrm{pH} 7.3$ and $20.0^{\circ} \mathrm{C}$. From [25].

$\mathrm{pH} 7.3$ and $20.0^{\circ} \mathrm{C}$. From [24].

$\mathrm{pH} 7.1$ and $20.0^{\circ} \mathrm{C}$. Present study.

$\mathrm{pH} 7.5$ and $20.0^{\circ} \mathrm{C}$. From [19].

${ }^{\mathrm{f}} \mathrm{pH} 7.3$ and $20.0^{\circ} \mathrm{C}$. From [19].

and exit from the $M$. leprae trHbO heme-distal pocket, the so-called 'E7-gate' being inoperative $[15,41]$.

\section{Conclusions}

The catalytic parameters for peroxynitrite-mediated reduction of heme- $\mathrm{Fe}(\mathrm{IV})=\mathrm{O}$ (present study) and heme- $\mathrm{Fe}(\mathrm{II})-\mathrm{O}_{2}$ are similar (Table 1) and high enough to indicate that both reactions could occur in vivo [7,15]. Peroxynitrite scavenging by heme- $\mathrm{Fe}(\mathrm{IV})=0$, obtained by treatment with $\mathrm{H}_{2} \mathrm{O}_{2}$, could be relevant under anaerobic and oxidative conditions, as occurs in ischemia-reperfusion injury and other cardiovascular pathological situations $[3,7,10]$. In turn, peroxynitrite can act as a scavenger of the highly oxidizing heme- $\mathrm{Fe}(\mathrm{IV})=0$ species, which could be responsible for the oxidative cell damage [42]. Therefore, heme-globins can undertake within the same cycle $\mathrm{H}_{2} \mathrm{O}_{2}$ and peroxynitrite detoxification.

\section{Acknowledgments}

This work was partially supported by grants from the Ministry for Education, University, and Research of Italy (Department of Biology, University Roma Tre, Roma, Italy, 'CLAR 2009' to P.A.) and from the Ministry of Welfare of Italy (National Institute for Infectious Diseases I.R.C.C.S. 'Lazzaro Spallanzani', Roma, Italy, 'Ricerca corrente 2009' to P.A.).

\section{Appendix A. Supplementary data}

Supplementary data associated with this article can be found, in the online version, at doi:10.1016/j.bbrc.2009.09.050.

\section{References}

[1] J.S. Beckman, W.H. Koppenol, Nitric oxide, superoxide, and peroxynitrite: the good, the bad, and the ugly, Am. J. Physiol. 271 (1996) C1424-C1437.

[2] C. Ducrocq, B. Blanchard, B. Pignatelli, H. Oshima, Peroxinitrite: an endogenous oxidizing and nitrating agent, Cell. Mol. Life Sci. 55 (1999) 1068-1077.

[3] R.S. Ronson, M. Nakamura, J. Vinten-Johansen, The cardiovascular effects and implications of peroxynitrite, Cardiov. Res. 44 (1999) 47-59. 
[4] L.J. Ignarro, Nitric oxide as a unique signaling molecule in the vascular system: a historical overview, J. Physiol. Pharmacol. 53 (2002) 503-514.

[5] E. Clementi, E. Nisoli, Nitric oxide and mitochondrial biogenesis: a key to longterm regulation of cellular metabolism, Comp. Biochem. Physiol. 142 (2005) 102-110.

[6] A. Denicola, R. Radi, Peroxynitrite and drug-dependent toxicity, Toxicology 208 (2005) 273-288.

[7] S. Herold, A. Fago, Reactions of peroxynitrite with globin proteins and their possible physiological role, Comp. Biochem. Physiol. A Mol. Integr. Physiol. 142 (2005) 124-129.

[8] M.H. Zaki, T. Akuta, T. Akaike, Nitric oxide-induced nitrative stress involved in microbial pathogenesis, J. Pharmacol. Sci. 98 (2005) 117-129.

[9] A. Olmos, R.M. Giner, S. Máñez, Drugs modulating the biological effects of peroxynitrite and related nitrogen species, Med. Res. Rev. 27 (2007) 1-64.

[10] S. Goldstein, G. Merényi, The chemistry of peroxynitrite: implications for biological activity, Methods Enzymol. 436 (2008) 49-61.

[11] L. Liaudet, G. Vassalli, P. Pacher, Role of peroxynitrite in the redox regulation of cell signal transduction pathways, Front. Biosci. 14 (2009) 4809-4814.

[12] M. Brunori, Nitric oxide moves myoglobin centre stage, Trends Biochem. Sci. 26 (2001) 209-210.

[13] J.B. Wittenberg, B.A. Wittenberg, Myoglobin function reassessed, J. Exp. Biol. 206 (2003) 2011-2020.

[14] M. Angelo, A. Hausladen, D.J. Singel, J.S. Stamler, Interactions of NO with hemoglobin: from microbes to man, Methods Enzymol. 436 (2008) $131-168$.

[15] P. Ascenzi, P. Visca, Scavenging of reactive nitrogen species by mycobacterial truncated hemoglobins, Methods Enzymol. 436 (2008) 317-337.

[16] D.A. Greenberg, K. Jin, A.A. Khan, Neuroglobin: an endogenous neuroprotectant, Curr. Opin. Pharmacol. 8 (2008) 20-24.

[17] S. Herold, T. Matsui, Y. Watanabe, Peroxynitrite isomerization catalyzed by his64 myoglobin mutants, J. Am. Chem. Soc. 123 (2001) 4085-4086.

[18] S. Herold, K. Shivashankar, M. Mehl, Myoglobin scavenges peroxynitrite without being significantly nitrated, Biochemistry 41 (2002) 13460-13472.

[19] S. Herold, M. Exner, F. Boccini, The mechanism of the peroxynitrite-mediated oxidation of myoglobin in the absence and presence of carbon dioxide, Chem. Res. Toxicol. 16 (2003) 390-402.

[20] N. Romero, R. Radi, E. Linares, O. Augusto, C.D. Detweiler, R.P. Mason, A Denicola, Reaction of human hemoglobin with peroxynitrite. Isomerization to nitrate and secondary formation of protein radicals, J. Biol. Chem. 278 (2003) 44049-44057.

[21] S. Herold, The outer-sphere oxidation of nitrosyliron(II)hemoglobin by peroxynitrite leads to the release of nitrogen monoxide, Inorg. Chem. 43 (2004) 3783-3785.

[22] F. Boccini, S. Herold, Mechanistic studies of the oxidation of oxyhemoglobin by peroxynitrite, Biochemistry 43 (2004) 16393-16404.

[23] S. Herold, A. Fago, R.E. Weber, S. Dewilde, L. Moens, Reactivity studies of the $\mathrm{Fe}(\mathrm{III})$ and $\mathrm{Fe}(\mathrm{II}) \mathrm{NO}$ forms of human neuroglobin reveal a potential role against oxidative stress, J. Biol. Chem. 279 (2004) 22841-22847.
[24] S. Herold, A. Puppo, Oxyleghemoglobin scavenges nitrogen monoxide and peroxynitrite: a possible role in functioning nodules?, J Biol. Inorg. Chem. 10 (2005) 935-945.

[25] P. Ascenzi, M. Milani, P. Visca, Peroxynitrite scavenging by ferrous truncated hemoglobin GlbO from Mycobacterium leprae, Biochem. Biophys. Res. Commun. 351 (2006) 528-533.

[26] S. Herold, F. Boccini, NO release from MbFe(II)NO and $\mathrm{HbFe}(\mathrm{II}) \mathrm{NO}$ after oxidation by peroxynitrite, Inorg. Chem. 45 (2006) 6933-6943.

[27] P. Ascenzi, M. Fasano, Abacavir modulates peroxynitrite-mediated oxidation of ferrous nitrosylated human serum heme-albumin, Biochem. Biophys. Res. Commun. 353 (2007) 469-474.

[28] P. Ascenzi, A. Bocedi, G. Antonini, M. Bolognesi, M. Fasano, Reductive nitrosylation and peroxynitrite-mediated oxidation of heme-hemopexin, FEBS J. 274 (2007) 551-562.

[29] P. Ascenzi, E. De Marinis, P. Visca, C. Ciaccio, M. Coletta, Peroxynitrite detoxification by ferryl Mycobacterium leprae truncated hemoglobin $\mathrm{O}$, Biochem. Biophys. Res. Commun. 380 (2009) 392-396.

[30] E. Antonini, M. Brunori, Hemoglobin and Myoglobin in their Reactions with Ligands, 1971, North-Holland Publishing Co., Amsterdam, London.

[31] H. Østdal, B. Daneshvar, L.H. Skibsted, Reduction of ferrylmyoglobin by $\beta$-lactoglobulin, Free Radic. Res. 24 (1996) 429-438.

[32] D.S. Bohle, P.A. Glassbrenner, B. Hansert, Syntheses of pure tetramethylammonium peroxynitrite, Methods Enzymol. 269 (1996) 302-311.

[33] W.H. Koppenol, R. Kissner, J.S. Beckman, Syntheses of peroxynitrite: to go with the flow or on solid grounds?, Methods Enzymol 269 (1996) 296-302.

[34] S. Goldstein, J. Lind, G. Merényi, Chemistry of peroxynitrites and peroxynitrates, Chem. Rev. 105 (2005) 2457-2470.

[35] S. Herold, F.J. Rehmann, Kinetic and mechanistic studies of the reactions of nitrogen monoxide and nitrite with ferryl myoglobin, J. Biol. Inorg. Chem. 6 (2001) 543-555.

[36] S. Herold, F.J. Rehmann, Kinetics of the reactions of nitrogen monoxide and nitrite with ferryl hemoglobin, Free Radic. Biol. Med. 34 (2003) 531-545.

[37] H. Bateman, Solution of a system of differential equations occurring in the theory of radioactive transformations, Proc. Cambridge Philos. Soc. 15 (1910) 423-427.

[38] M.F. Perutz, Myoglobin and haemoglobin: role of distal residues in reactions with haem ligands, Trends Biochem. Sci. 14 (1989) 42-44

[39] M. Bolognesi, D. Bordo, M. Rizzi, C. Tarricone, P. Ascenzi, Nonvertebrate hemoglobins: structural bases for reactivity, Prog. Biophys. Mol. Biol. 68 (1997) 29-68.

[40] P. Ascenzi, A. Bellelli, M. Coletta, A. Colosimo, G. Falcioni, G.M. Giacometti, R. Ippoliti, L. Zolla, B. Giardina, Multiple strategies for $\mathrm{O}_{2}$ transport: from simplicity to complexity, IUBMB Life 59 (2007) 600-616.

[41] P. Visca, G. Fabozzi, M. Milani, M. Bolognesi, P. Ascenzi, Nitric oxide and Mycobacterium leprae pathogenicity, IUBMB Life 54 (2002) 95-99.

[42] A.I. Alayash, R.P. Patel, R.E. Cashon, Redox reactions of hemoglobin and myoglobin: biological and toxicological implications, Antioxid. Redox Signal. 3 (2001) 313-327. 